\title{
Social Services of Sardar Kaure Khan Jatoi in Subcontinent during Colonial Period under Islamic Concept
}

Sohail Akhtar* and Abdul Razaq

Department of History, Ghazi University, Dera Ghazi Khan, Pakistan

"Corresponding author: Dr Sohail Akhtar, Department of History, Ghazi University, Dera Ghazi Khan, Pakistan, Tel: +92 64 9260135; E-mail: sohailakhtar252@gmail.com

Rec date: June 26, 2017; Acc date: July 18, 2017; Pub date: July 30, 2017

Copyright: (C) 2017 Akhtar S, et al. This is an open-access article distributed under the terms of the Creative Commons Attribution License, which permits unrestricted use, distribution, and reproduction in any medium, provided the original author and source are credited.

\begin{abstract}
Social services are very important element of the society. A social worker always works for the uplift of the society without any religious or political concern. His aim of life is only to serve the mankind through education, health and other deeds of welfare without any personal benefits. A social worker always sacrifices his interest and feelings. He works for the pleasure of poor and needy. As Famous poet Allama Muhammad Iqbal said, "There are countless people who love God, But I follow the person who love the creature of God".

The Islam is a religion of peace, prosperity, love, brotherhood, kindness, generosity, equality. It advises the followers to serve the mankind. Virtue is the name of good behaviour. God loves those who love his creatures. It is said that, history always keeps alive and remembers one who spent life for the benefits of humanity. In this regard, we have seen many important political, religious, social and literary personalities in the world. These personalities had played a vital role to up-lift the socio-political and economic status of their people. Among these personalities Sardar Kaure Khan Jatoi of District Muzaffargarh in Pakistan was most prominent, undisputable and a leading personality for his social services. He has a significant place in the society of Muzaffargarh during the colonial rule in sub-continent. His efforts were marvellous. He contributed and reformed in the field of Education, Health and other human concern matters. He is called as Hatim Tai of Muzaffargarh District. He served at that time when people were living a life of a slave. This research paper is an effort to highlight the contribution of Sardar Kaure Khan Jatoi in the socio-cultural services in the district Muzaffargarh (Table 1).
\end{abstract}

Keywords: Islam; Devote; Kaure Khan; Bequeathed; Education; Health; Social services

\section{Introduction}

Islam is the most prominent religion in the universe and it emphasis on his believers to spend in the way of Allah Almighty. It advises the followers to help the poor and needy so that you might win the blessing, will and grace of Allah. You do not achieve a high rank in virtue till at that when you spend your most precious thing. In this regard the followers are serving the mankind from the time of the Holy Prophet. There countless event when the followers presented all their property in way of Allah Almighty. Sardar Kaure Khan Jatoi was also a strong believer of Allah Almighty and he had strong belief on the service the humanity. His social services are magnificent during the colonial period in India.

\section{Social Services of Sardar Kaure Khan Jatoi}

For this research paper the methodology was adopted on historic method. All primary and secondary sources were used to collect the data about this topic. The Holy Quran and Hadieth of the prophet is an explanation of the teaching of Islam. While, with concerning period the District Gazetteer, Census Reports, Revenue Record, Record District Council, Educational and Health Record, Books, Bequeathed of Kaure Khan, Newspaper, interviews and a set of questions also proved useful for this research paper.

Allah Almighty says in the Holy Quran;
"You will never receive any good reward without spending your most precious and lovely thing. Never will you attain the good (reward) until you spend (in the way of Allah) from that which you love"

Islam motivated the followers if they send on the humanity they will granted a best reward. "The person who spends his money in the way of Allah Almighty, his example is like a grain's seed grows countless. And Allah multiplies (His reward) for whom He wills. And Allah is allEncompassing and Knowing".

"Those who spend their wealth in the way of Allah and then do not follow up what they have spent. Allah will grant a best reward to them. These are the people which have no fear and nor any mourn".

Khan Bahadur Sardar Kaure Khan Jatoi was a leading personality of Tehsil Jatoi District Muzaffargarh. Sardar Kaure khan Jatoi was born in 1800 A.D at the house of Sardar Saaid Khan 4th a Jatoi Baloch Sardar. Jatoi Baloch is a major Baloch Tribe and belongs to Jattu Khan the son of Famous Baloch Sardar Mir Jalal Khan First who came from Iran to Makran (Balochistan) [1].

Jatoi Tribe is an important tribe of Sindh and Districts Muzaffargarh and Dera Ghazi Khan in Punjab. A large population of this tribe is found in the southern part of the District Muzaffargarh at Tehsils Jatoi and Alipur [1]. Sardar Kaure Khan Jatoi was a kind-hearted personage of this backward region during the colonial Period. He was a wellknown reformer and Government recognize his social services. Kaure Khan gained the fame due to his wisdom, sincerity, Generosity, kindness, and his high standard of thoughts. His single objective was to 
serve the humanity. He was God fearing person and he devoted a large share of his property for the welfare of the people through bequeathed in the last quarter of the 19th century when people were unaware from social services or NGOs.

$\mathrm{He}$ is the name of success in those days when there was lack of sources. In 20th century Muzaffargarh was one of the most backward District of Sub-continent. Poverty, illiteracy, ill health, was the common problems in Pakistan not only in District Muzaffargarh. Sardar Kaure Khan Jatoi was the person who was working for the improvement of his people. He was a rich man and generous too. He worked successfully on his mission of the service of humanity despite of sources. According to him, he was unknown from the word failure, he had only known the word success. He had liked honour, estate and climax.

He was not a theocratic as he looked but he only loved human beings. Humanity was his creed by religious point of view. He was unknown the religious group. He accepted all the creeds. All kinds of people were his friend and brothers. He never felt him a rich man, but he also said he is the servant of the poor. He always joined the sorrows and grieves of the people of his area and he shared their problems. That's why he was called a real leader of the people of the district Muzaffargarh in the British period of ruling [2].

British government appointed him Honorary Magistrate. At Jatoi he established his own Jail and court. His justice is famous in the District. He was granted the title of "Khan Bahadar" by the British government. $\mathrm{He}$ also remained member of district board [2]. He was the first reformer of the district. He worked for the betterment of the people for that propose he established schools and dispensaries in district Muzaffargarh. Jatoi, Alipur Schools and dispensary is their major work done by Sardar Kaure Khan in 19th century. He established boys primary school Jatoi in 1886. He also established Kaure Hospital of jatoi. The main road of Alipur to Jatoi and Jatoi to Shahjamal and Chock Qureshi were constructed by his donation. Saradr Kaure Khan also donated for the construction of Chenab Bridge on this condition that no tool tax will be received by the public on this bridge [3].

He was not literate, but he loved to education and literate people. Unfortunately, he was childless, but he was owner of large fertile land in Muzaffargarh, Rahimyarkhan and Rajanpur districts. He divided his property into three parts as per Muslim Personal Law or Muhammadan Law of inheritance. One part was donated for the promotion of education in the far-flung areas of the country. and remaining two parts went to his four wives and other relatives [4]. He was the first man in the sub-continent in 19th century who donated his assets for education. His land was very fertile which located in the delta of five rivers. He was unique in this zone because there were many feudal lords. We are looking him at the biggest philanthropic donors of 18th and 19th century

He was childless that's why he devoted 82753 Kanal land to the district board. His Waseet Nama (Bequeathed) was written in 1894 and the property was transferred to district board in 1897 [5]. Sardar Kaure Khan devoted 10344 acres land for the welfare of the poor people. This land was transferred to district board in 1897. This land was consisting on old barren or irrigated land. It was remained to the relatives of Sardar Kaure Khan till at 1960 on lease. After 1960 district council divided this land in 247 lots (parts) and each lot had 400 kanals land, after 1962 district council has given this land to different people on lease. The lease is given through an advertisement. In 1997-98 the land was again divided in 415 Lots and each lot has 200 Kanals [6].

\begin{tabular}{|c|c|c|c|c|}
\hline District & No. of Moza & No. of Lots & Kanal/ Marlas & Acres \\
\hline Muzaffargarh & 23 & 406 & $72149-3$ & 9019 \\
\hline Rajanpur & 9 & 9 & $10604-11$ & 1325 \\
\hline Total & 32 & 415 & $82753-14$ & 10344 \\
\hline
\end{tabular}

Table 1: Distribution of land.

He bequeathed to give his $3 / 9$ properties for the welfare of the people. The land was transferred to district board in 1897. The income of the property was Rs 8000 per month. He worked for the well fare of the education and health. He was a reformer and he served people in education from his property. He announced that any Muslim' child wants to acquire from any institution education he is ready to bear his expenses. He announced a lot amount of scholarship particularly for the children of Baloach tribe [7].

There were 20 scholarships of Kaure Khan for the secondary school students and for the needy students of the district [8] Sardar Kaure Khan primary school Jatoi has been working since 1886 and it's all expenses are bear by the devoted property of Sardar Kaure Khan Jatoi. $\mathrm{He}$ also constructed several Masjids also. He always respected the people who came at his door and demanded something he granted him without any hesitation. He always helped the needy. $\mathrm{He}$ constructed many Masjid some of them are the Msjid Kotla Band Ali, Masjid Jatoi, Masjid Mazhar Pul, Masjid Peer Wali are most famous Masjids. The annual income of his waqf property is almost one Karor. His services were like as a welfare trust, he worked on education and health of the people in the district at that time when people did not know about any welfare organization. He was died on May 15, 1896 [9].

His social services are important for the up gradation of the society in Muzaffargarh. He set a noble example to devote his property for the welfare of humanity when there was no concept of such tradition. $\mathrm{He}$ died sonless. Sardar Kaure Khan bequeathed and devoted 3/9 of his property which was 82753 Kanal or 10344 Acres in two districts Muzaffargarh and Rajanpur 9019 acres and 1325 respectively to Government for the well-being of the people in education and health 0510-1884. That property was transferred to District board in 1897 A.D. It is one of the largest devoted property by any social individual in the history. He also gave about Rs 8000/. Per annum to district board for use of stipends for Muslims scholars in 1929 [10].

\section{Discussion}

In education sector besides the interest shown by the Government, the part played by a local Anjamn-e-Islamia Muzaffargarh in 
popularizing education amongst Muslims is command able. Anjamn was established by a Muslim Lawyer and public prosecutor Sardar Abdul Hameed Khan Dasti in 1920. Sardar Kaure Khan Jatoi also had a significant role. The stipends awarded from Sardar Kaure Khan Jatoi funds and the recruitment of Muslims from Agriculture Class in training institutions in pre-independence days directly influenced school attendance with rose immensely [11].

In fee relaxation the poor children, the children of agriculturalist, village artisans and Kammis (lower class people) in this district enjoyed a remission of half the fees with a view to provide financial aid to the needy pupils the Sardar Kaure Khan Scholarship were awarded Rs 4/- per Month in 1960 which was a handsome amount [12].

In addition to these stipends of the value of about Rs 14000/ are awarded every year out of the income of the late Khan Bahadur Sardar Kaure Khan's estate left to the District Muzaffargarh, District Council Muzaffargarh to deserving and needy scholars in Schools, Secondary Schools, Colleges and in unusual cases in professional colleges. He also established a primary school in 1876 which was the first single school in that area [13].

The district Gazetteer also mentioned that the Hospital of Jatoi was established by Sardar Kaure Khan. In 1875 for the poor people. Government upgraded it in the memorial of Late Khan Bahadur Sardar Kaure Khan who left to the district Council a share of his estate [14].

This bequeath land was not utilized as per will of the donor till the creation of Pakistan in 1947. Influential people earned millions of rupees by cultivating crops, by cutting trees, exploiting the herbs etc. Exploiters became millionaire for 53 years. After creation of Pakistan, this land was given to District Council Muzaffargarh as custodian of the land, but this institution was honey combed with many sided corruptions. Its officials leased out this land to their relatives and other well-wishers on throwaway prices. During the PPP regime, the property transferred to Auqaf department, but leases could not be changed. Chief Martial Administrator General Zia-ul-Haq returned this property to District Council in 1982 and he ordered to utilize this property according the will of the donor. The first Public school was established in Jatoi (a birth place of Sardar Kaure Khan in 1983. which was now upgraded as Higher Secondary School. After it another School was established in Muzaffargarh in the name of donor. Now there are four Kaure Khan Schools. In the year 1991, Government of Punjab introduced a new scheme of establishing D.P.S system at division and district levels. Commissioner Dera Ghazi Khan Division and Chairman Zila Council Muzaffargarh after mutual consultation decided to run this school under D.P.S scheme by giving it autonomy. Under this scheme, this school was to be run by its own generated funds. However, the Zila Council supported the school for six years out of the income from Sardar Kaure Khan's land because it was not possible to run it by its own resources at that time [15].

At the time of its conversion to DPS status, the strength of school was 202 (boys and girls) with yearly income from fees Rs 1.5 Lac against yearly expenditures about Twenty Lac. After shifting the school to the new management on 30-6-1991, a Governing Body was formed with commissioner as its Chairman and Deputy Commissioner as Vice Chairman. However, with the advent of new local Government system in 2001, DCO became the Chairman of the Governing Body. Sardar Kaure Khan Public School Muzaffargarh was registered as Secondary School boys and girls in the year 1994 and Higher Secondary School in the year 2002 [16].
The above discussion very clearly shows that Khan Bahadur Sardar Kaure Khan was great treasure of the district and his struggle was in the favour of the people of district Muzaffargarh. He sincerely worked for the benefits of his people. Especially his devotion for education and health is a key point for the social development of the society. Those who spend their wealth (in Allah's way) by night and by day, secretly and publicly they will have their reward with their Lord and no fear will there be concerning them, nor will they grieve (Figure 1).

Allah Almighty Created the man for the help of other people. The angels are enough for his prayer. The prayer, (Deen) Religion and belief is that a man must help the other in this world.

\section{Conclusion}

This paper is first original attempt to explore the social service of Kaure Khan Jatoi which changed the destination of the people of the area. The socio-economic condition improved due to the foundation of educational and other social institutions long ago when the people of the area were deprived from their fundamental rights. It was due to his sincere and sincere efforts that we have seen a social change in the district before the end of the 19th century. His established institutes have become prominent level educational institutes now. The cost of his property is in millions of Rupees. He proved himself as a real wellwisher of the humanity.

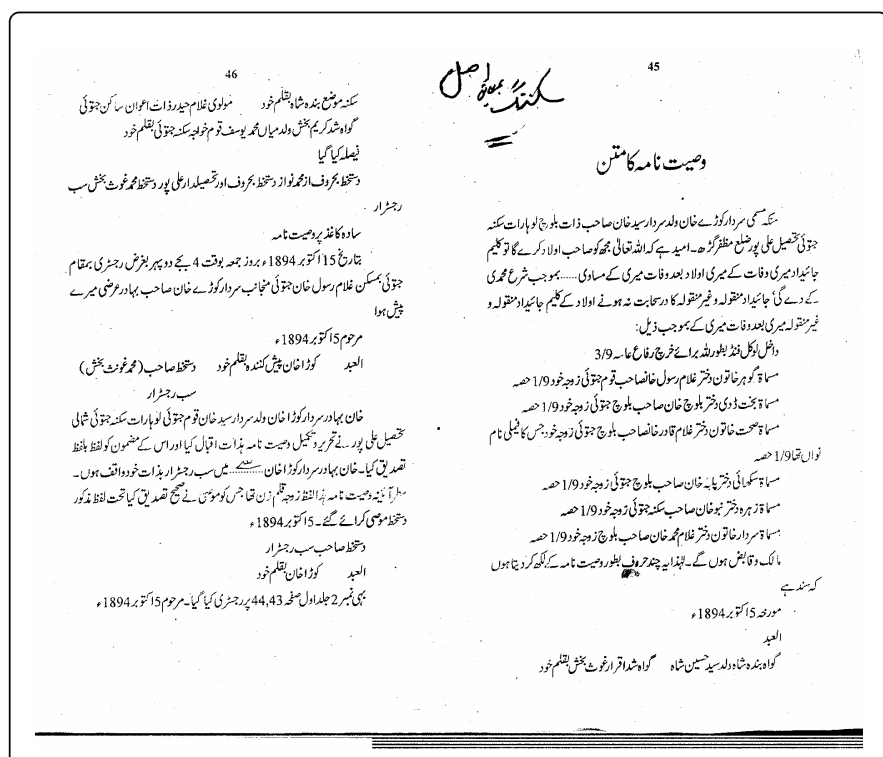

Figure 1: Hieroglyphics of ancient Islamic Era.

\section{References}

1. Ram H (1929) Gul Bahar, Balochi Academy, Quetta, Pakistan. p. 45.

2. District Gazetteer (1929) District Muzaffar Garh, Pakistan. p. 311.

3. Daily Jang (2007) Multan, Pakistan. p.10.

4. Jatoi SAQ (2008) Ex. District Nazim and MNA, Pakistan.

5. Sardar Kaure Khan (1984) Bequeathed of Sardar Kaure Khan, Pakistan.

6. Property Record of Sardar Kaure Khan, Record district Council Muzaffargarh.

7. Muhammad BK (2008) Jadeed, Tareekh Muzaffargarh, Multan, Pakistan. p.45.

8. Property Record, Sardar Kaure Khan, District Council Muzaffargarh. 
Citation: Akhtar S, Razaq A (2017) Social Services of Sardar Kaure Khan Jatoi in Subcontinent during Colonial Period under Islamic Concept. J Socialomics 6: 212. doi:10.4172/2167-0358.1000212

Page 4 of 4
9. Muhammad BK (2008) Jadeed, Tareekh Muzaffargarh, Multan. Pakistan.
13. District Gazetteer (1929) District Muzaffar Garh, Pakistan. p.285 p.44.
14. District Census Report (1961) District Muzaffar Garh. Pakistan.
10. District Gazetteer (1929) Pakistan. p.286.
15. Record District Council, Muzaffargarh.
11. District Gazetteer (1929) District Muzaffar Garh, Pakistan. p.281.
16. Record Kaure Khan School Muzaffargarh.
12. District Gazetteer (1929) District Muzaffar Garh, Pakistan. p.284. 